\title{
Performance evaluation of nanofluids in solar energy: a review of the recent literature
}

\author{
Navid Bozorgan ${ }^{1 *}$ and Maryam Shafahi ${ }^{2}$
}

\begin{abstract}
Utilizing nanofluid as an absorber fluid is an effective approach to enhance heat transfer in solar devices. The purpose of this review is to summarize the research done on the nanofluids' applications in solar thermal engineering systems in recent years. This review article provides comprehensive information for the design of a solar thermal system working at the optimum conditions. This paper identifies the opportunities for future research as well.
\end{abstract}

Keywords: Nanofluids; Solar energy; Solar systems; Heat transfer enhancement

\section{Introduction}

Energy is an important entity for the economic development of any country. On the other hand, fossil fuels meeting a great portion of the energy demand are scarce and their availability is decreasing continously. Nowadays, solar systems play an important role in the production of energy from renewable sources by converting solar radiation into useful heat or electricity. Considering the environmental protection and great uncertainty over future energy supplies, solar energy is a better alternative energy form in spite of its its slightly higher operation costs. Heat transfer enhancement in solar devices is one of the significant issues in energy saving and compact designs. One of the effictive methods is to replace the working fluid with nanofluids as a novel strategy to improve heat transfer characteristics of the fluid. More recently reserachers have become interested in the use of nanofluids in collectors, water heaters, solar cooling systems, solar cells, solar stills, solar absorption refrigeration systems, and a combination of different solar devices due to higher thermal conductivity of nanofluids and the radiative properties of nanoparticle. How to select suitable nanofluids in solar applications is a key issue. The effectiveness of nanofluids as absorber fluids in a solar device strongly depends on the type of nanoparticles and base fluid, volume fraction of nanoparticles, radiative

\footnotetext{
* Correspondence: N.Bozorgan@gmail.com

${ }^{1}$ Mechanical Engineering Department, Abadan Branch, Islamic Azad University, P.O.B. 666, Abadan, Iran

Full list of author information is available at the end of the article
}

properties of nanofluids, temperature of the liquid, size and shape of the nanoparticles, $\mathrm{pH}$ values, and stability of the nanofluids [1]. It was found that only a few review papers have discussed the capability of nanofluids to enhance the performance of solar systems [2-5].This paper compiles recent research in this field and identifies many issues that are open or even not commenced to investigate. It is authors' hope that this review will be useful to determine the effectiveness of nanofluids in solar applications.

\section{Literature review of recent years \\ Using nanofluids in solar collectors \\ Role of nanoparticles}

Gan et al. [6] experimently showed that the radiation absorption of $\mathrm{Al}_{2} \mathrm{O}_{3}$ nanofluids is less than Aluminuim nanofluids. For nanofluids with $\mathrm{Al}_{2} \mathrm{O}_{3}$ particles, the situation is different because of the different optical properties of $\mathrm{Al}_{2} \mathrm{O}_{3}$. The weak radiation absorption of $\mathrm{Al}_{2} \mathrm{O}_{3}$ nanoparticles will not result in significant localized convective heat transfer from the particles to the base fluids. The use of $\mathrm{Al}_{2} \mathrm{O}_{3}$ /water nanofluid as coolant was simulated for a silicon solar cell using the finite element method by Elmir et al. [7]. They considered the solar panel as an inclined cavity with a slope of $30^{\circ}$. Application of nanofluids increased the average Nusselt number and rate of cooling. They reported $27 \%$ enhancement in the heat transfer rate for $10 \%$ alumina nanofluid at $R e=5$.

Luo et al. [8] simulated the performance of a DAC solar collector with nanofluids using a $2 \mathrm{D}$ model by solving the radiative transport equations of particulate 
media and combining conduction and convection heat transfer equations. The nanofluid flows horizontally from right to left in a steady-state solar collector covered with a glass plate. A solar radiation simulator is used to validate their model. They prepared nanofluids by dispersing and oscillating $\mathrm{TiO}_{2}, \mathrm{Al}_{2} \mathrm{O}_{3}, \mathrm{Ag}, \mathrm{Cu}, \mathrm{SiO}_{2}$, graphite nanoparticles, and carbon nanotubes into Texatherm oil. Their results show that the use of nanofluid in solar collector can improve the outlet temperature and efficiency. They also found that the efficiency of most nanofluids are similar and larger than that of oil, except for $\mathrm{TiO}_{2}$.

Rahman et al. [9] performed a numerical study for a triangular shape solar collector with nanofluids by Galerkin weighted residual finite element method for a wide range of Grashof numbers (Gr). The corrugated bottom is kept at a constant high temperature and the side walls of the triangular enclosure are kept at a low temperature as seen in Figure 1. It is assumed that both fluid phase and nanoparticles are in thermal equilibrium and there is no slip between them. Nanofluid is Newtonian and incompressible, and flow is laminar and unsteady. Constant thermophysical properties are considered for the nanofluid except for the density variation in the buoyancy forces determined by using the Boussinesq approximation.
Nevertheless, they have not mentioned the particle's diameters. The authors concluded that high value of both $\mathrm{Gr}$ and solid volume fraction confirms better heat transfer through convection and conduction. Results showed $24.28 \%$ improvement for $\mathrm{Gr}=10^{6}$ at $10 \%$ volume fraction of copper particles. For lower values of Gr number, conduction is the primary mode of heat transfer for any value of solid volume fractions. The results showed that the convective heat transfer performance is better when the solid volume fraction is kept at 0.05 or 0.08 . This study also showed that cu-water nanofluid is the best nanofluid for the augmentation of heat transfer.

Faizal et al. [10] investigated the thermal performance of nanofluid solar collector and its contribution size reduction to estimate the cost saving. Their findings indicated that efficiency of solar collector with nanofluids is calculated by the function of working fluid density, specific heat and mass flow rates. The results confirmed that higher density and lower specific heat of nanofluids offers higher thermal efficiency than water and can reduce the solar collector area about 25.6\%, 21.6\%, 22.1\% and $21.5 \%$ for $\mathrm{CuO}, \mathrm{SiO}_{2}, \mathrm{TiO}_{2}$ and $\mathrm{Al}_{2} \mathrm{O}_{3}$ nanofluids as seen in Figure 2. Hence, it will reduce the weight, energy and cost to manufacture the collector. The average value of 220 MJ embodied energy can be saved for each

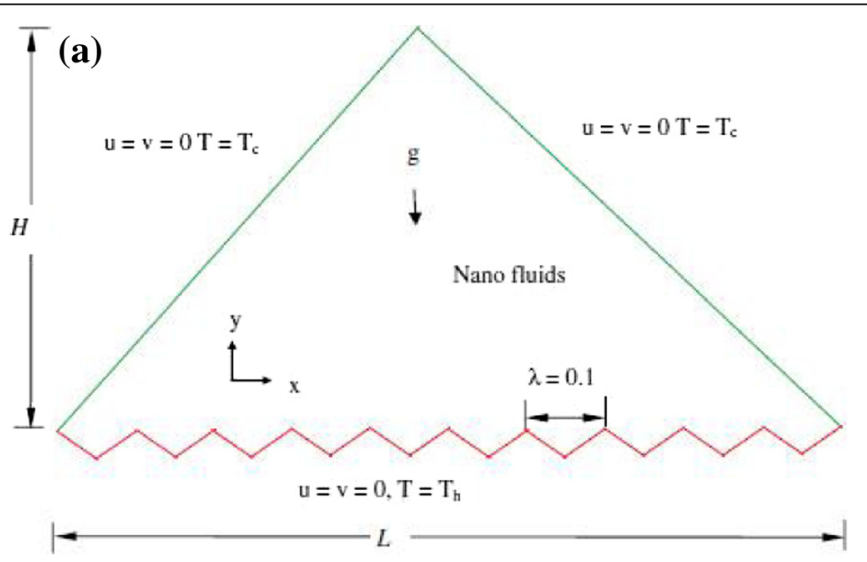

(b)

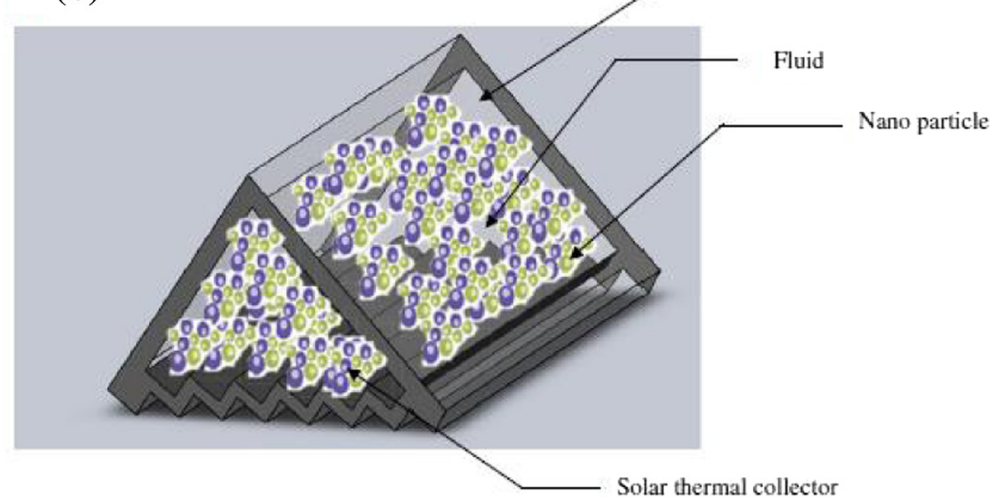

Figure 1 (a) Schematic of the triangular shape collector (b) 3D view of a solar thermal collector filled with nanofluid [9]. 


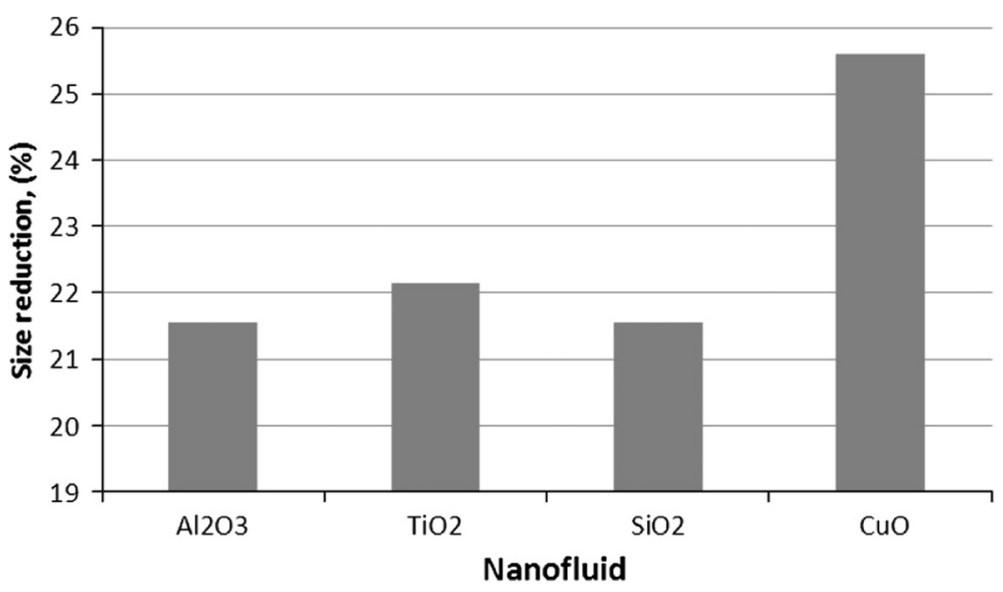

Figure 2 Percentage of size reduction for solar collector by applying different nanofluids.

collector, 2.4 years payback period can be achieved and around $170 \mathrm{~kg}$ less $\mathrm{CO}_{2}$ emissions will be the result of using nanofluid based solar collector compared to a conventional one. Environmental damage cost is also lower with the nanofluid based solar collector.

Parvin et al. [11] numerically investigated the effects of the nanoparticle volume fraction $(\phi=0 \%, 1 \%, 3 \%, 5 \%$ and $7 \%$ ) and the Reynolds number $(\operatorname{Re}=200,400,600$, 800 and 1000) on the temperature distribution, rate of entropy generation, and collector efficiency. The working fluid was incompressible $\mathrm{Cu}$-water nanofluid under a laminar regime. Their findings were as follows: a) Increasing the particles concentration raises the fluid viscosity and decreases the Reynolds number and consequently decreases heat transfer. b) It is important to find the optimum volume fraction of nanoparticle for each application. c) The collector efficiency can be enhanced nearly 2 times by using $\mathrm{Ag}$-water and $\mathrm{Cu}$-water nanofluids with concentration of $3 \%$ as seen in Figure $3 \mathrm{~d}$ ) The entropy generation is enhanced up to $\phi=3 \%$ as seen in Figure 3. After this level, adding more nanoparticles makes no changes in mean entropy generation.
Ladjevardi et al. [12] numerically studied the effects of using nanofluid on the performance of a solar collector as seen in Figure 4 considering the different diameter and volume fractions of graphite nanoparticles. They observed that in the infrared domain, the water optical characteristics are dominant while in the UV and visible ranges extinction coefficients are dependent on nanoparticle volume fractions. The extinction coefficient is calculated from the absorption and scattering efficiencies in this research. Their numerical results showed that nanofluid collector thermal efficiency increases about $88 \%$ compared with the one in pure water collector with the inlet temperature of $313 \mathrm{~K}$. It also can be increased to $227 \%$ with the inlet temperature of $333 \mathrm{~K}$.

Filho et al. [13] studied silver nanoparticles as direct sunlight absorbers for solar thermal applications. Their results showed that the maximum stored thermal energy increases by $52 \%, 93 \%$ and $144 \%$ for silver particle concentration of $1.62,3.25$ and $6.5 \mathrm{ppm}$ respectively due to the good photothermal conversion properties of silver nanoparticles. They also observed that the
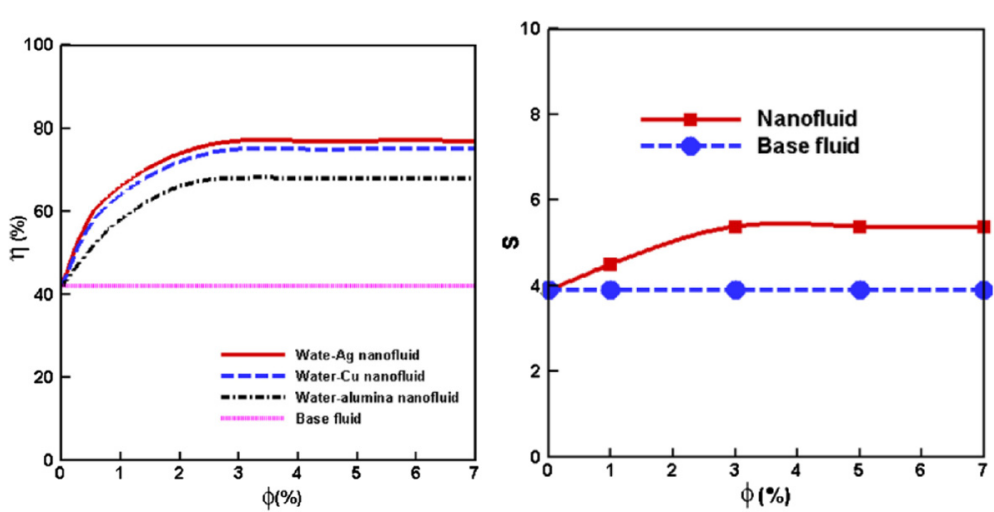

Figure 3 Collector efficiency ( $\eta$, mean entropy generation ( $S$ ) and Bejan number (Be) at various concentrations. 


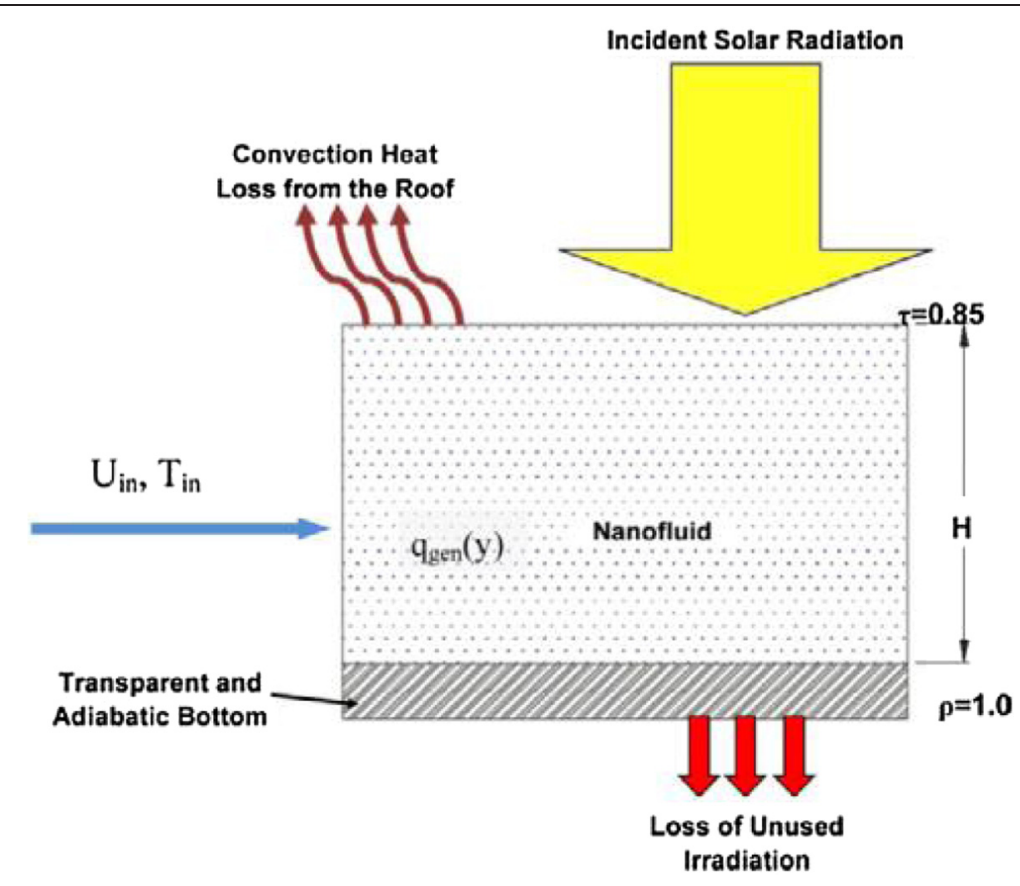

Figure 4 Schematic of volumetric solar collector.

influence of particle concentration on the specific absorption rate (SAR) is only discernable at the initial heating period. It was concluded that reduction in the SAR at higher particle loadings (65 and $650 \mathrm{ppm}$ ) might be the result of: (i) The formation of agglomerates and reduction in the intensity of the sunlight into the fluid due to the deposited particles on the surface, (ii) The difference in the absorption efficiency of each particle at different fluid depth, (iii) The heat leak through radiation may become strengthened as the particle concentration exceeds a certain value as seen in Figures 5,6 and 7.

Karami et al. [14] experimentally showed that aqueous suspension based alkaline functionalized carbon nanotubes (f-CNT), $10 \mathrm{~nm}$ in diameter and $5-10 \mu \mathrm{m}$ in length, has good stability as an absorber fluid in lowtemperature Direct Absorption Solar Collector (DASC). The reason is associated with the hydrophilic nature of carboxylate groups. f-CNT considerably reduces the transmittance and enhances the thermal conductivity as seen in Figure 8. They recommended the use of this kind of nanofluids to absorb the light directly. In this study, $\mathrm{f}$-CNTs was dispersed into the water by an ultrasonic instrument with the volume fractions less than $150 \mathrm{ppm}$. Higher concentrations produced a black solution which light was not able to pass through it.

Said et al. [15] found that nanofluids with single wall carbon nanotubes (SWCNTs) in a flat plate solar collector showed the minimum entropy generation compared to the nanofluids prepared by suspending $\mathrm{Al}_{2} \mathrm{O}_{3}, \mathrm{TiO}_{2}$ and $\mathrm{SiO}_{2}$ nanoparticles in the same base fluid as seen in Figure 9. They attributed the decrease of the entropy generation to the increase in heat flux on the absorber plate due to the nanoparticles addition. Ultrasonicator and high pressure homogenizer (capacity of up to 2000 bar) is used to disperse the nanoparticles into the water. It was observed the SWCNTs nanofluids could reduce the entropy generation by $4.34 \%$ and enhance the heat transfer coefficient by $15.33 \%$. It also had a small penalty in the pumping power by $1.2 \%$.

Tang et al. [16] prepared the carbon nanotube/PEG/ $\mathrm{SiO}_{2}$ composites with high thermal conductivity from multiwall carbon nanotubes (MWCNTs), poly (ethylene glycol) (PEG) and inorganic $\mathrm{SiO}_{2}$. These composites had higher thermal conductivity than traditional phasechange materials (PCMs) because of the high thermal conductivity of MWCNTs. Their results clearly showed that PEG/ $\mathrm{SiO}_{2} / \mathrm{MWCNT}$ composites can effectively improve the efficiency of solar energy applications.

Saidur et al. [17] investigated the effects of different parameters on the efficiency of a low-temperature nanofluidbased direct absorption solar collector (DAC) with water and aluminum nanoparticles. One big advantage of using low-temperature systems is that solar collectors can be relatively simple and inexpensive. Additionally, there are a number of working fluids suitable to lowtemperature operation. Commonly used base liquids are 


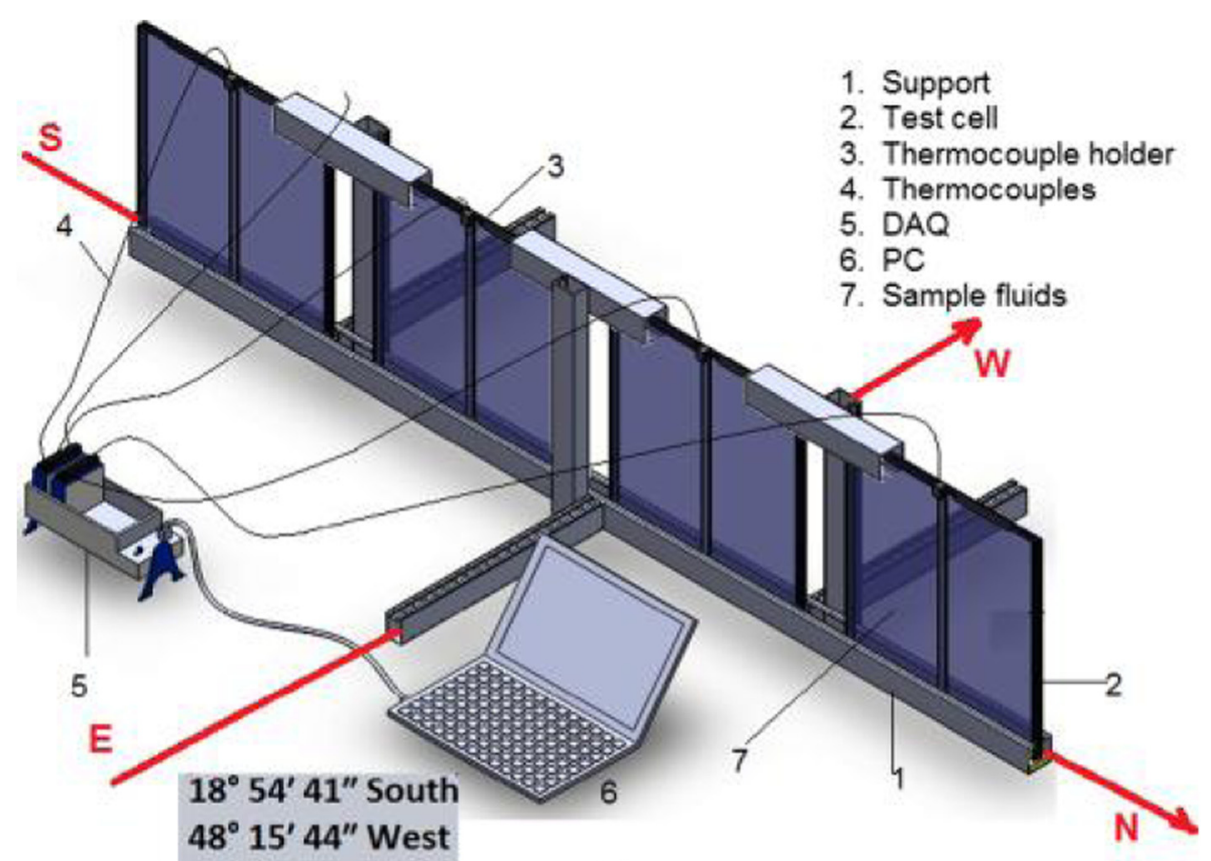

(a)

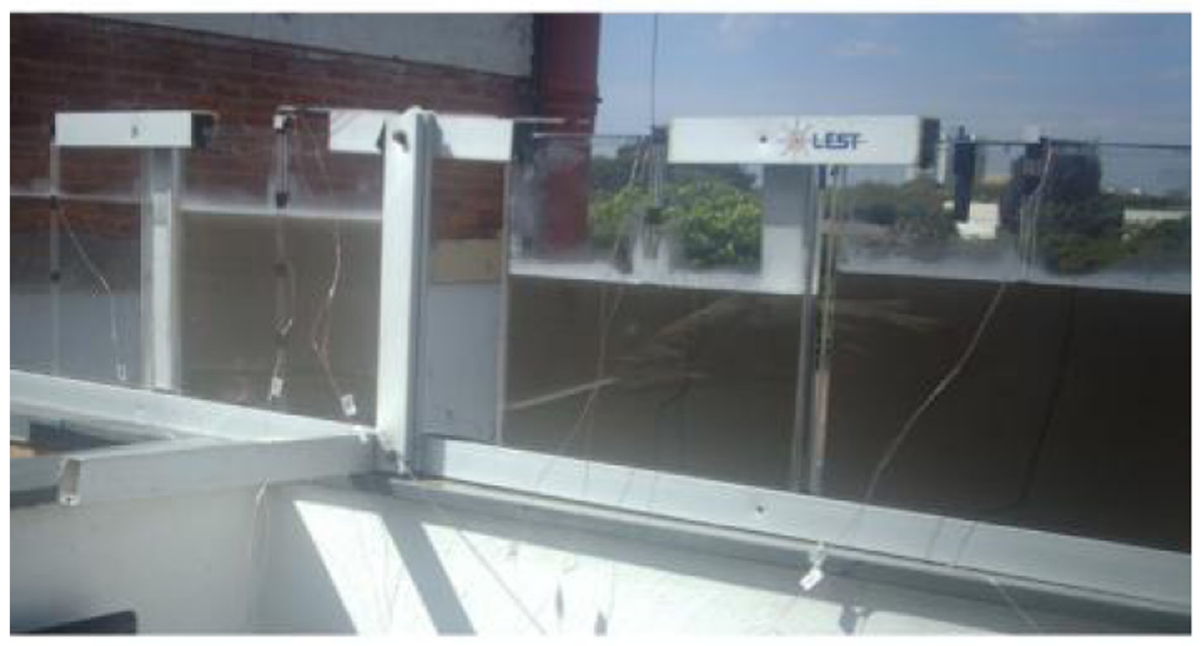

(b)

Figure 5 Experimental system: (a) a schematic illustration and (b) a snapshot of the system under direct sunlight on top of a roof.

water, oil, and ethylene glycol. They accounted for the effects of absorption and scattering within the nanofluid to evaluate the intensity distribution within the nanofluid by the radiative transfer equation (RTE). In order to calculate the spectral extinction coefficient of the nanofluid that is sum of scattering coefficient and absorption coefficient, they investigated the optical properties of the based fluid and nanoparticles separately. Their results revealed that Aluminum/water nanofluid with $1 \%$ volume fraction improves the solar absorption considerably. They found that the effect of particle size on the optical properties of nanofluid is minimal, but in order to have Rayleigh scattering the size of nanoparticles should be less than $20 \mathrm{~nm}$. They also found that the extinction coefficient is linearly proportionate to volume fraction.

Sokhansefat et al. [18] numerically investigated the heat transfer enhancement for $\mathrm{Al}_{2} \mathrm{O}_{3} /$ synthetic oil nanofluid with concentrations up to $5 \%$ in a parabolic trough collector tube at different operational temperatures as seen in Figure 10. Nanofluid enhanced convective heat transfer coefficient as seen in Figure 11. 


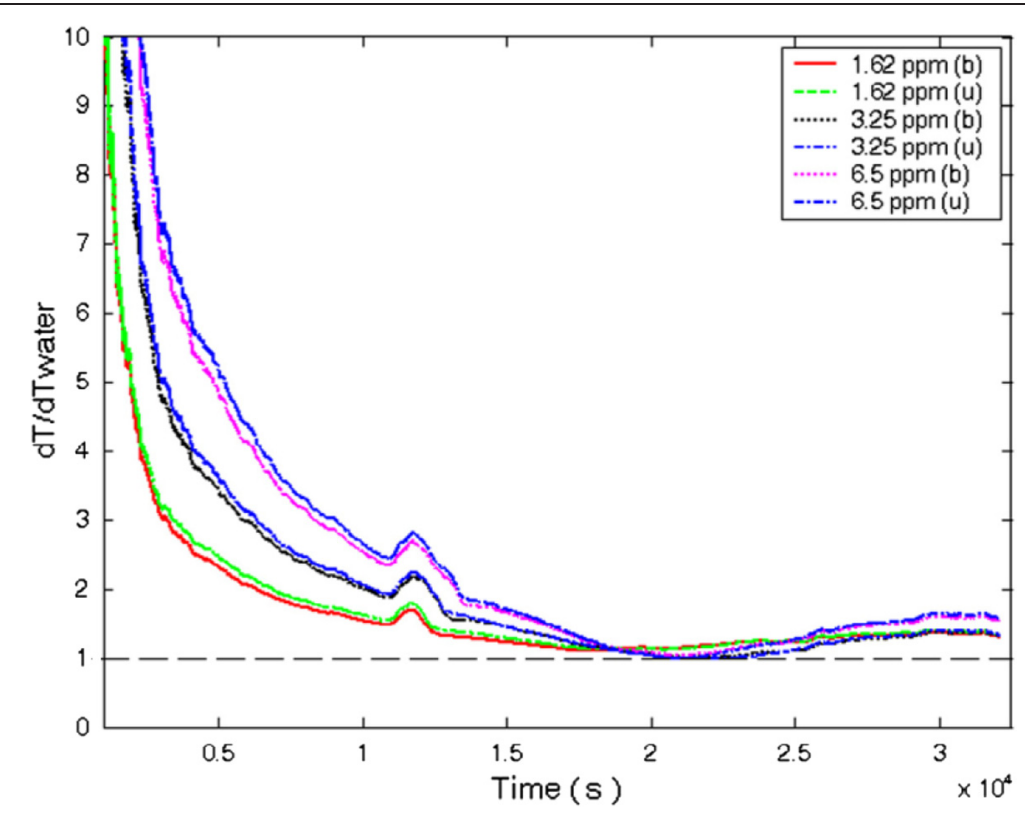

Figure 6 Comparison of the ratio of stored thermal energy at different concentrations (where b and $\mathrm{u}$ refer to thermocouples located at the bottom and upper positions respectively).

Nasrin et al. [19] performed a numerical study to investigate the influence of Prandtl number on the flow, temperature fields, convective and radiated heat transfer rates, mean bulk temperature of the fluids and average velocity field in a solar with water- $\mathrm{Al}_{2} \mathrm{O}_{3}$ nanofluid collector as seen in Figure 12. The results showed that with increasing Pr from 1.73 to 6.62, the convective heat transfer enhances about $26 \%$ and $18 \%$ for nanofluid and base fluid respectively whereas the radiation enhances by $8 \%$.

\section{Role of base fluid}

Colangelo et al. [20] experimently showed that the thermal conductivity improvement of the nanofluids with diathermic oil is greater than that with water in high temperature applications such as solar collectores. They observed that the thermal conductivity reduced with increasing the size of nanoparticles.

Hordy et al. [21] made four different nanofluids by dispersing plasma functionalized multi-walled carbon

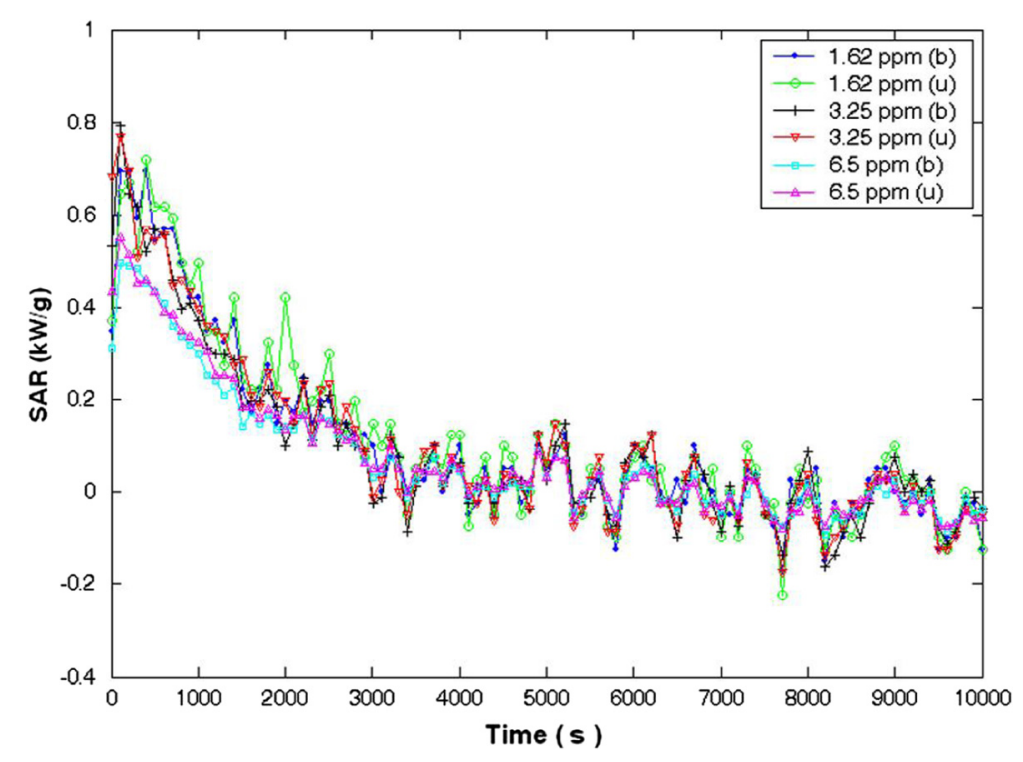

Figure 7 Specific absorption rate of silver nanoparticles (where b and u refer to thermocouples located at the bottom and upper positions respectively). 


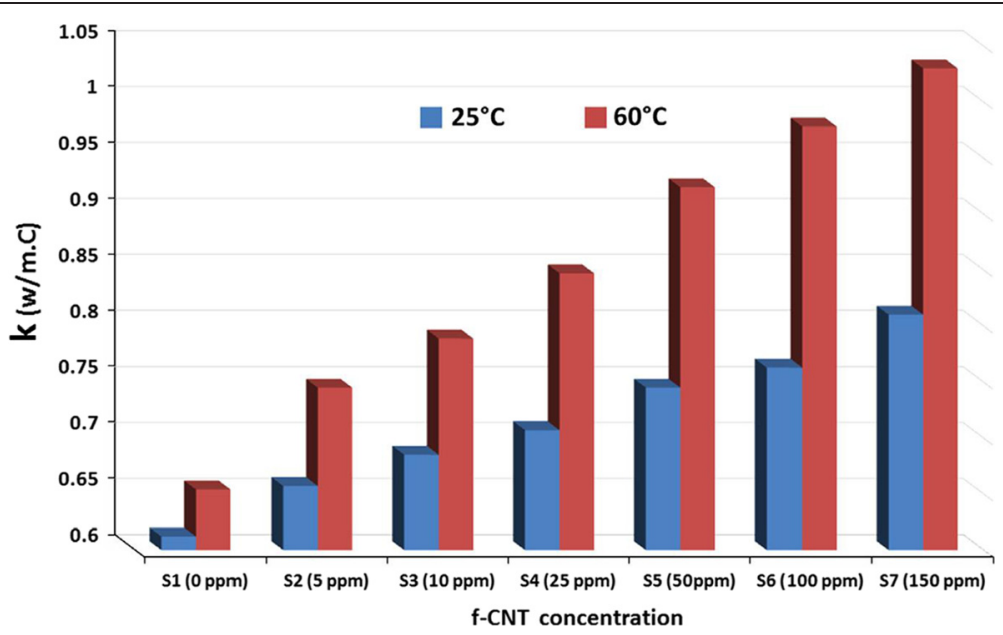

Figure 8 Thermal conductivity of $\mathrm{f}$-CNT/water NFs in ambient temperature and $60^{\circ} \mathrm{C}$.

nanotubes (MWCNTs) in water, ethylene glycol, propylene glycol and Therminol VP-1 heat transfer fluids with the aid of an ultrasonic bath. They examined both the long-term and high-temperature stability of CNT nanofluids for use in direct solar absorption. In this work plasma treatment applied to modify the surface of the MWCNTs to improve their dispersion property within the base fluid. This study reported a quantitative demonstration of the high temperature and long-term stability of ethylene glycol and propylene glycol-based MWCNT nanofluids for solar thermal collectors.

Said et al. [22] experimentlly investigated the thermal conductivity, viscosity and pressure drop of water, ethylene glycol (EG) and EG + H2O (60:40)-based Al2O3 $(13 \mathrm{~nm})$ nanofluids prepared by using ultrasonic dispersion method in the operating temperature range of $25^{\circ} \mathrm{C}$ to $80^{\circ} \mathrm{C}$ at low range concentrations of $0.05 \%$ to $0.1 \%$ for. They observed that deviation of experimental values from estimated values of thermal conductivity of $\mathrm{Al}_{2} \mathrm{O}_{3}$ / water nanofluids is considerably high but the experimental values of $\mathrm{Al}_{2} \mathrm{O}_{3} / E G$ nanofluids are nearly similar to those of the model calculation as seen in Figure 13. Their results showd that nanofluids pressure drop at a low concentration flowing in a solar collector is slightly higher than the base fluid.

Liu et al. [23] experimentally investigated the feasibility of using the graphene (GE)-dispersed nanofluids based on the ionic liquid 1-hexyl-3-methylimidazolium tetrafluoroborate ([HMIM] $\mathrm{BF}_{4}$ ) in high-temperature heat transfer systems (such as solar collectors). Ionic liquids (ILs) are a group of molten salts with a melting below $100^{\circ} \mathrm{C}$ as well as a wide liquid temperature range from room temperature to a maximum temperature of $459^{\circ} \mathrm{C}$. ILs have excellent thermophysical properties such as good thermal and chemical stability, high density and heat capacity and negligible vapor pressure. In

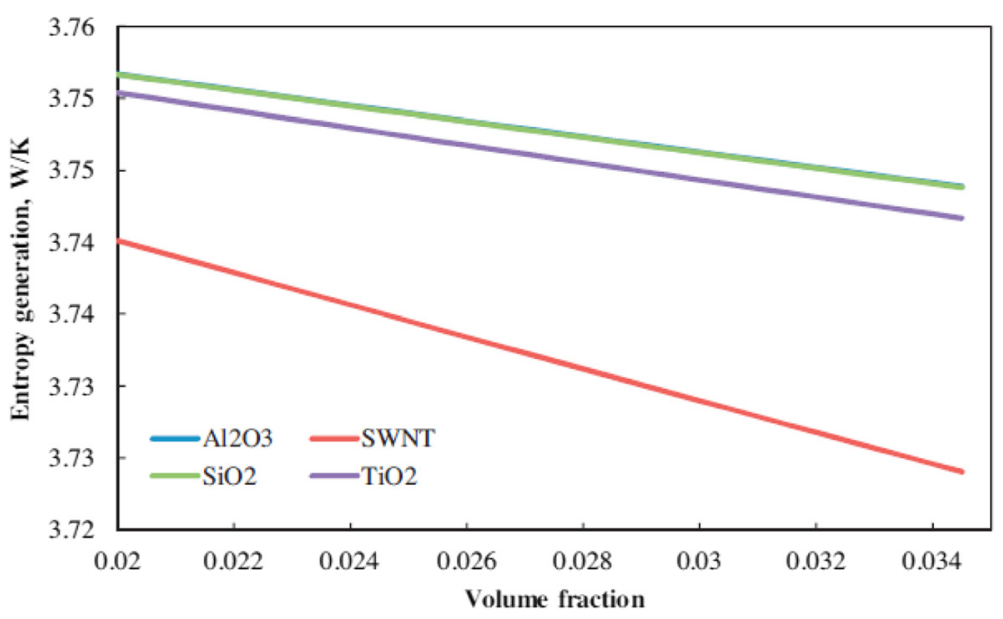

Figure 9 Change of entropy generation with volume fraction. 


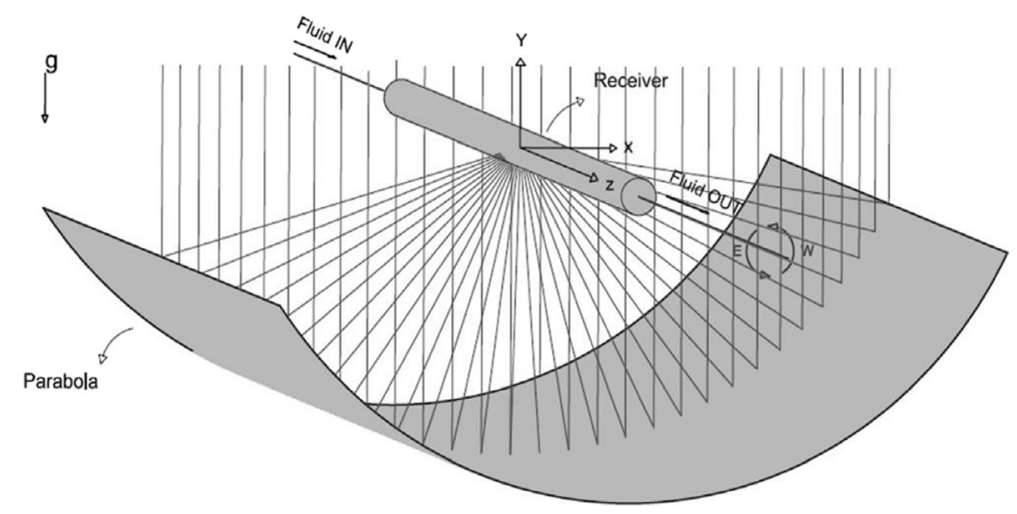

Figure $\mathbf{1 0}$ Schematic diagram of the parabolic trough collector and absorber tube.

this work, authors showed how to improve the performance of ILs for solar thermal systems. They observed 15.2\%-22.9\% enhancement in thermal conductivity using $0.06 \%$ graphene in the temperature range from 25 to $200^{\circ} \mathrm{C}$ as seen in Figure 14. Their results showed that GE is a better nanoadditive for nanofluids than other carbon materials and metal nanoparticles.

The authors attributed this reduction to the selflubrication characteristic of GE. In addition, the results obtained from the thermogravimetric analysis showed the high thermal stability of $\mathrm{GE} / \mathrm{BF}_{4}$ nanofluids. Their measurements showed that this novel class of nanofluids is very suitable for high temperature applications such as solar collectors.

Ho et al. [24] found the optimal concentration of alumina nanoparticles in doped molten Hitec (a nitrate salt) by maximizing its specific heat capacity. Hightemperature molten salt typically has a high heat capacity and is effective as a working fluid for concentrating solar power (CSP) systems. Their findings are as follows: 1- The addition of less than $2 \% \mathrm{Al}_{2} \mathrm{O}_{3}$ nanoparticles

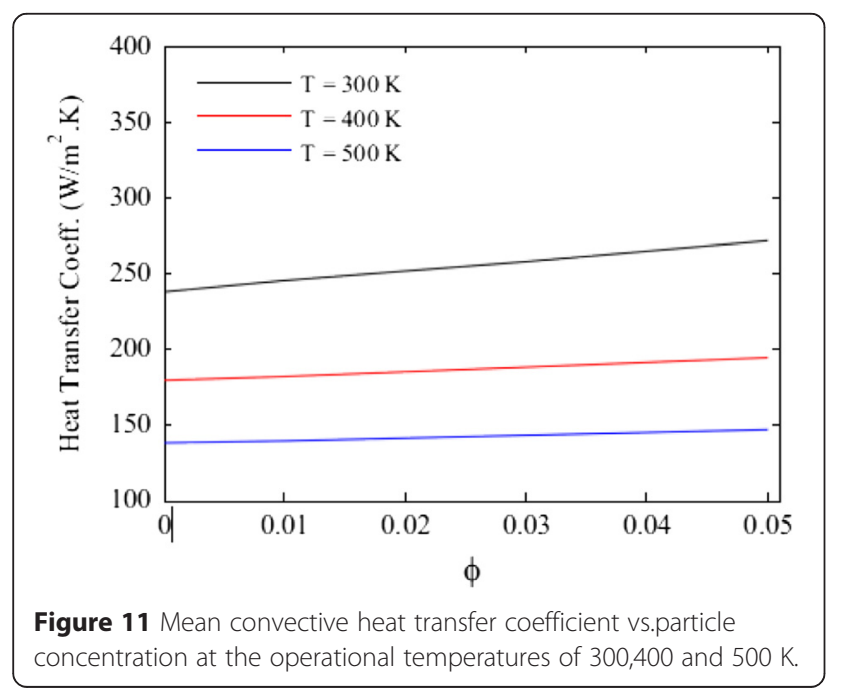

significantly increases the specific heat of Hitec metal at low temperatures as seen in Figure 15, 2- For the volume fractions less than or equal to $0.5 \%$, adding $\mathrm{Al}_{2} \mathrm{O}_{3}$ nanoparticles has a negative effect on the specific heat in temperature of $335^{\circ} \mathrm{C}$, 3- At all temperatures, a concentration of $0.063 \mathrm{wt} . \%$ provides the maximum enhancement of specific heat about 19.9\%, 4- The scanning electron microscopic (SEM) images show that, even at a relatively low concentration, nanoparticles aggregate as clusters with the size of 0.2 to $0.6 \mu \mathrm{m}$ in the grain boundaries of Hitec, 5- The findings of this study suggest that the concentration that yields favorable uniform dispersion and optimal pattern of particles or clusters may maximize the specific heat. The simplified model of the solid-fluid interfacial area demonstrates that interfacial area is maximal at a concentration of $0.023 \mathrm{wt} . \%$. As the nanoparticle concentration increases above 0.023 wt. \%, the formed clusters become larger and the interfacial area density between the solid clusters and the base fluid decreases which may reduce the increase in specific heat capacity. According to the results obtained from this study, the maximum enhancement of the specific heat capacity occurs at concentration of $0.063 \mathrm{wt} . \%$ instead of $0.023 \mathrm{wt} . \%$. Indeed, some agglomeration of nanoparticles forming submicrometer clusters may be the best for the enhancement of specific heat capacity. However, the total interfacial area at concentration of 0.063 wt. \% was slightly less than its value at concentration of $0.023 \mathrm{wt}$ \%.

\section{Role of surfactants}

Singh et al. [25] added $\mathrm{Cu}$ to commercial solar heat transfer fluids (Therminol 59 (TH59) and Therminol 66 (TH66)) by the combination of temperature and ultrasonic ripening processes. They stated that surfactant selection has an important role in preparing stable nanofluids. Choosing the right surfactant is mainly dependent on the properties of the base fluids and particles. For example, silicon oxide nanoparticles were successfully 


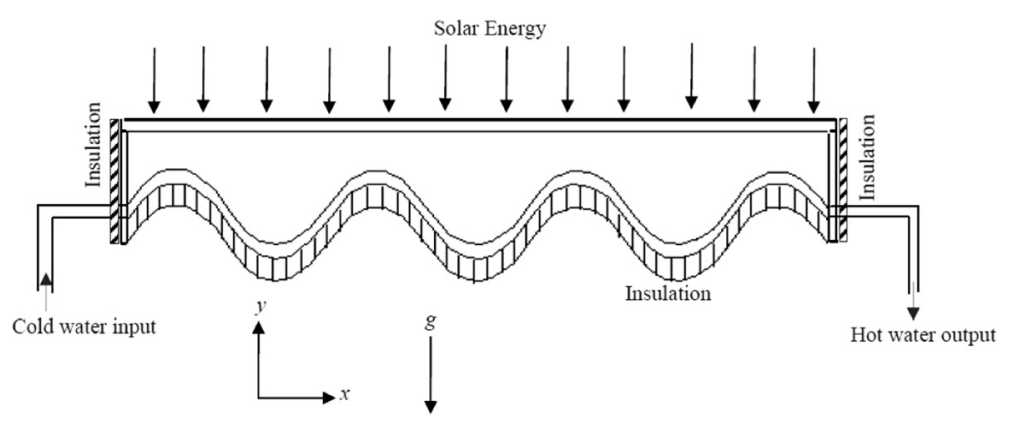

Figure 12 Schematic diagram of the solar collector.

dispersed in TH66 using benzalkonium chloride (BAC, Acros Organics) as a surfactant but the use of BAC surfactant with $\mathrm{Cu}$ nanoparticles did not provide sufficient stability of suspension due to the lack of specific interaction between the nanoparticles and the surfactant molecules. The bi-layer arrangement of surfactant molecules should provide good adhesion to the nanoparticle surface and miscibility with the aromatic solvent. In this work, authors used a combination of oleic acid and BAC and a mixture of octadecyl thiol (ODT) and BAC surfactants to disperse $\mathrm{Cu}$ nanoparticles in TH66 and TH59, respectively. They observed that $3 \mathrm{D} \mathrm{Cu}$ nanoparticle agglomerates do not break by conventional sonication with ultrasound gun without temperature ripening. They showed that a sonication time of about $4 \mathrm{~h}$ leads to the effective breakup of $\mathrm{Cu}$ agglomerates into individual grains at a $120^{\circ} \mathrm{C}$. They also concluded that $\mathrm{Cu} / \mathrm{TH} 66$ nanofluids appear to be more stable than the $\mathrm{Cu} / \mathrm{TH} 59$ nanofluids because of the higher dynamic viscosity.

Yousefi et al. [26,27] studied the effect of $\mathrm{Al}_{2} \mathrm{O}_{3}$ $(15 \mathrm{~nm})$ and MWCNT (10-30 nm) water nanofluid on the efficiency of a flat plate solar collector experimentally. The weight fractions of the nanoparticles were $0.2 \%$ and $0.4 \%$, and the experiments were performed with and without Triton X-100 as surfactant. Their findings showed that the surfactant presence in the nanofluid extremely affects solar collector's efficiency.

Lenert et al. [28] presented a combined modeling and experimental study to optimize the performance of a cylindrical nano-fluid volumetric receiver. They concluded that the efficiency is more than $35 \%$ when nanofluid volumetric receivers are coupled to a power cycle and optimized with respect to the optical thickness and solar exposure time. This study provides an important perspective in the use of nanofluids as volumetric receivers in concentrated solar applications. In this work, $28 \mathrm{~nm}$ carbon-coated cobalt (C-Co) nanoparticles dispersed and suspended in Therminol VP-1 after $30 \mathrm{~min}$ in a sonication bath without any surfactant.

\section{Role of the $\mathrm{pH}$}

Yousefi et al. [29] investigated the effect of $\mathrm{pH}$ of MWCNT-H2O nanofluid on the efficiency of a flat-plate solar collector as seen in Figure 16. The experiments were carried out using $0.2 \mathrm{wt} \%$ MWCNT $(10-30 \mathrm{~nm})$ with various $\mathrm{pH}$ values $(3.5,6.5$ and 9.5) and with Triton $\mathrm{X}-100$ as an additive. They found that increasing or decreasing the $\mathrm{pH}$ with respect to the $\mathrm{pH}$ of the
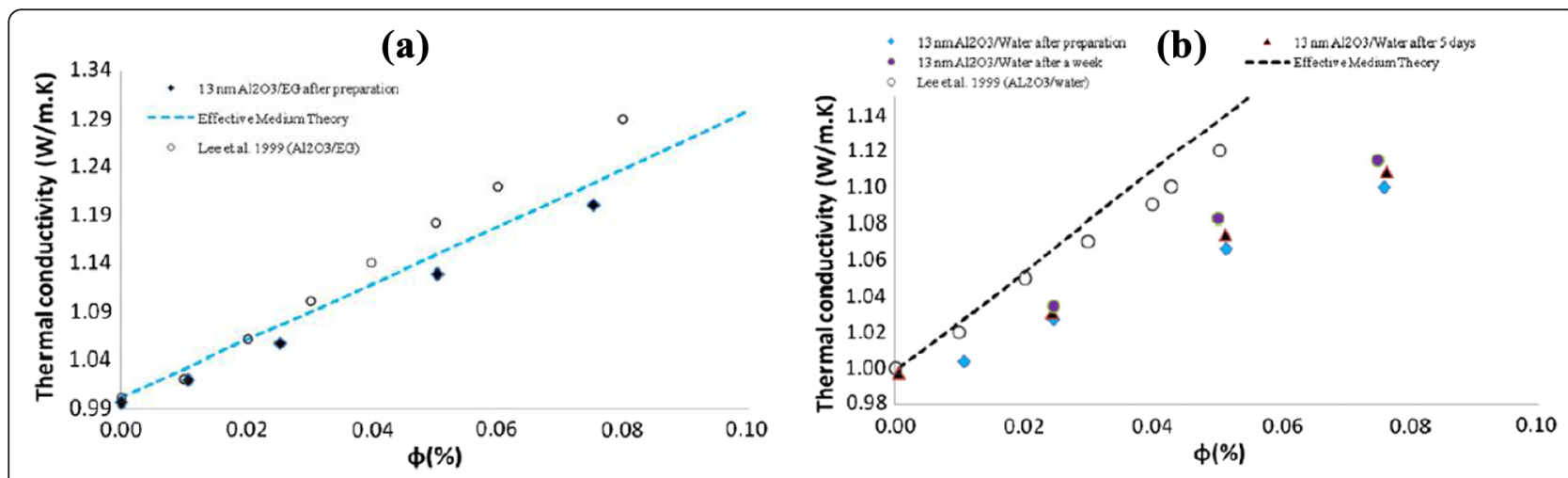

Figure 13 Thermal conductivity of Al2O3/EG (a) and Al2O3/water (b) nanofluids at different volume fractions and at $25^{\circ} \mathrm{C}$. 


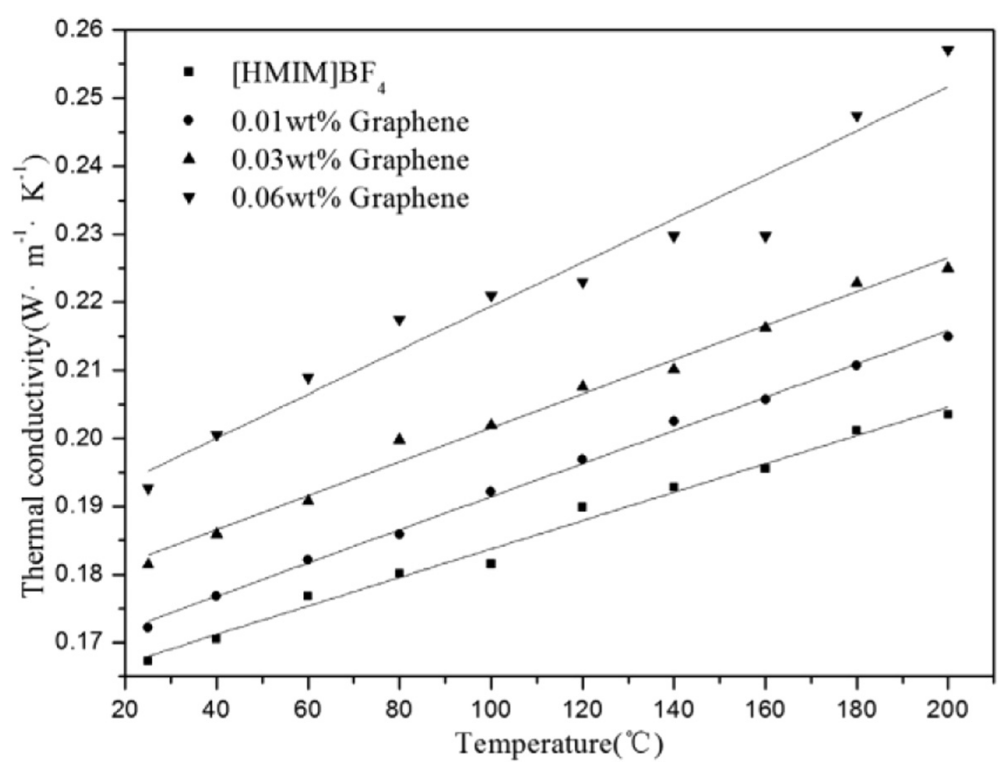

Figure 14 Thermal conductivity of [HMIM]BF4 and the GE-dispersed lonanofluids as a function of temperature.

isoelectric point (IEP) would enhance the positive effect of nanofluids on the efficiency of the solar collector. The collector efficiency enhanced while the differences between the $\mathrm{pH}$ of nanofluids and that of isoelectric increased. As the nanofluids become more acidic (lower $\mathrm{pH}$ value), more charges are accumulated on the particle surface, leading to lower agglomeration of nanoparticles in the suspension. Consequently, the effective thermal conductivity of the nanofluid increases. In addition, with the increase in $\mathrm{pH}$ of the nanofluid, the surface charge of the CNT increases leading to the increase in thermal conductivity and stability of nanofluid.
Using nanofluids in photovoltaic/thermal (PV/T) system Sardarabadi et al. [30] performed experiments to study the effects of using $\mathrm{SiO} 2 /$ water nanofluid as a coolant on the thermal and electrical efficiencies of a photovoltaic thermal $(\mathrm{PV} / \mathrm{T})$ system. A flat plate solar collector was attached to a PV panel. The tilt angle of the collector was set at a constant value of $32^{\circ}$ to maximize the solar collecting area. It was observed that by adding a thermal collector to a PV system, the total exergy for the three cases with pure water, $1 \%$ silica/water nanofluid and $3 \%$ silica/water nanofluid increased by $19.36 \%, 22.61 \%$ and $24.31 \%$, respectively as seen in Figure 17 . Thermal

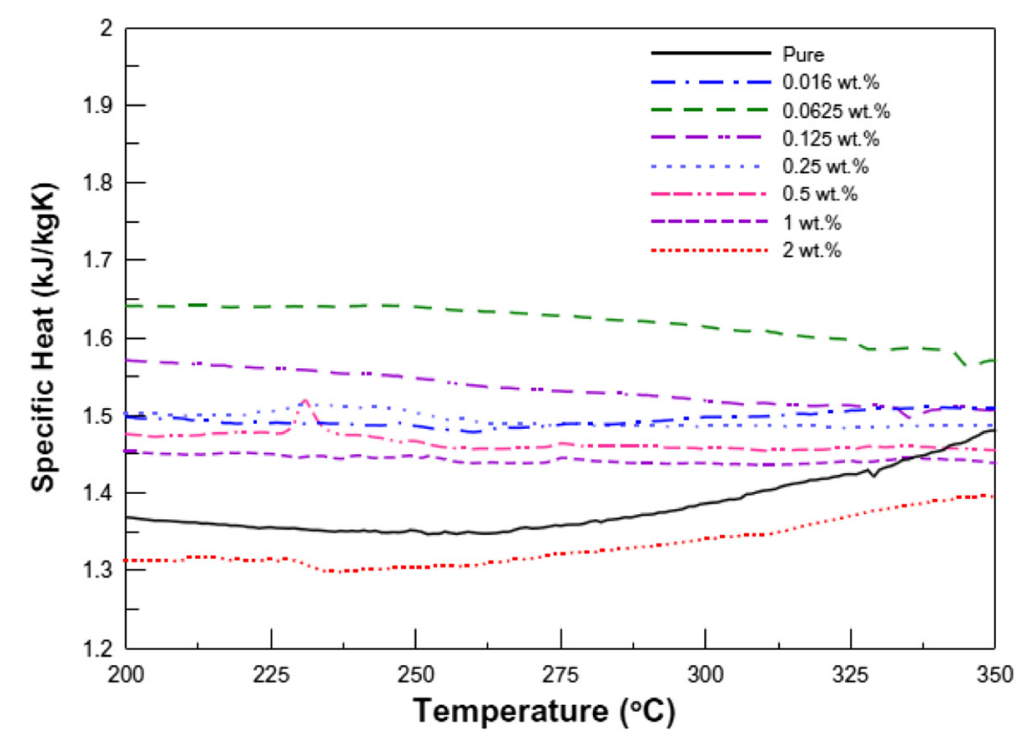

Figure 15 Variation of specific heat capacity with temperature for the pure and the different nanoparticle concentration of Hitec nanofluid. 


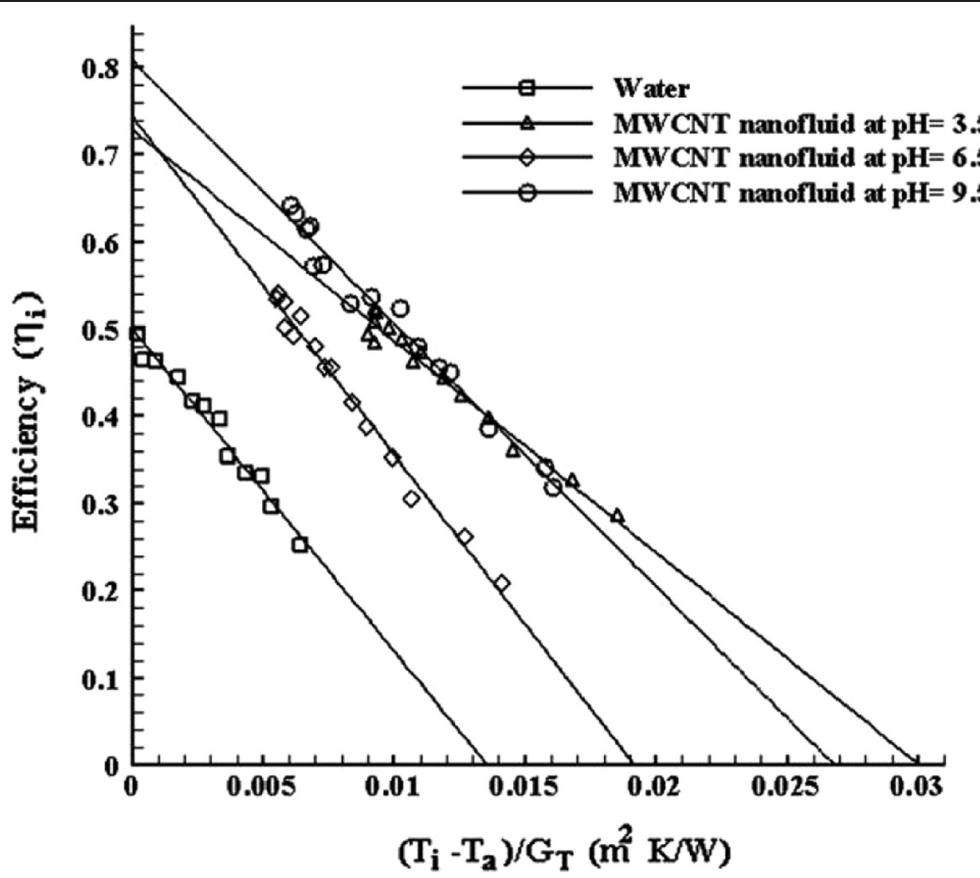

Figure 16 The efficiency of the flat-plate solar collector with MWCNT nanofluid as base fluid at three pH values as compared with water in $0.0333 \mathrm{~kg} / \mathrm{s}$ mass flow rate.

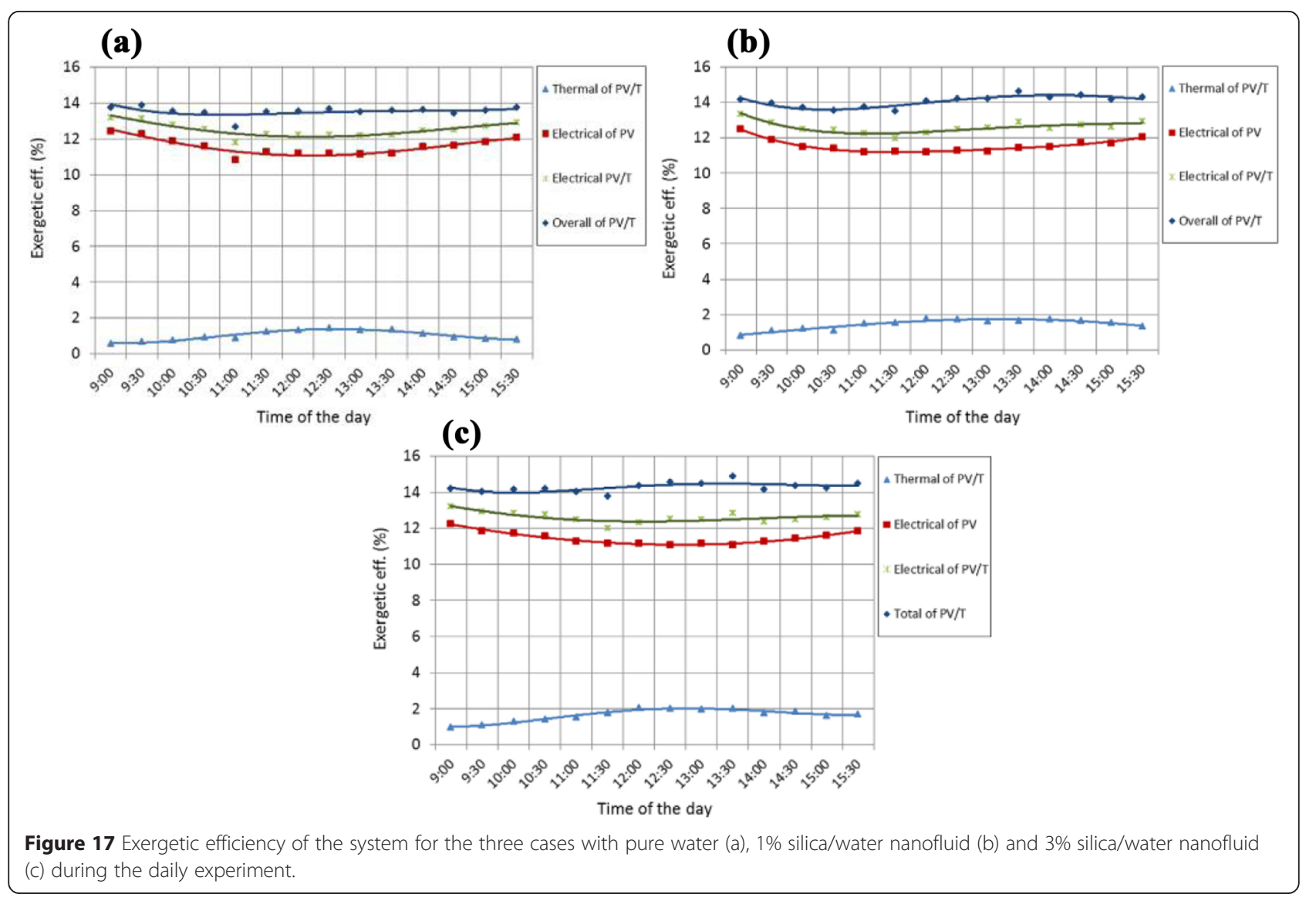


efficiency of the PV/T collector for the two cases of 1 and $3 \mathrm{wt} \%$ of silica/water nanofluid increased $7.6 \%$ and $12.8 \%$, respectively.

Karami et al. [31] experimentlly investigated the cooling performance of water based Boehmite $\left(\mathrm{AlOOH} . \mathrm{xH}_{2} \mathrm{O}\right)$ nanofluid in a hybrid photovoltaic (PV) cell. The PV cell is mono-crystalline silicon. Results showed that the nanofluid performed better than water and the average PV surface temperature decreased from $62.29^{\circ} \mathrm{C}$ to $32.5^{\circ} \mathrm{C}$ as seen in Figure 18. They reported that the electrical efficiency falls as the concentration of the nanofluid rises beyond a certain level. The authors attributed this reduction to the high surface activity of nanoparticles and their tendency to agglomeration/clustering at high particle loadings. Table 1 summarizes the results of nanofluids influence on different solar thermal applications.

\section{Using nanofluids in solar stills}

Kabeel et al. [32] investigated a small unit for water desalination coupled with nano-fluid-based ( $\mathrm{Cu} /$ water) solar collector as a heat source as seen in Figure 19. The system consists of a solar water heater (flat plate solar collector), a mixing tank and a flashing chamber plus a helical heat exchanger and a condenser. The desalination process is based on the evaporation of sea water under a very low pressure (vacuum). The evaporated water is then condensed to obtain fresh water. The simulation results showed that the nanoparticle concentration is an important factor on increasing the fresh water production and decreasing cost. Authors reported that the water cost can be decreased from 16.43 to $11.68 \$ / \mathrm{m}^{3}$ at $\phi=5 \%$ as seen in Figure 20.

Kabeel et al. [33] used $\mathrm{Al}_{2} \mathrm{O}_{3}$ nanoparticles with water inside a single basin solar still. Their results showed that using nanofluids improves the solar still water productivity by about $116 \%$ and $76 \%$ with and without operating the vacuum fan. The authors attributed this increment to the increase of evaporation rate inside the still. Utilizing nanofluid increases the rate of evaporation. In addition, due to this vacuum inside the still the evaporation rate increases further and the productivity increases compared with the still working at atmospheric conditions.

\section{Using nanofluids in solar pond}

$\mathrm{Al}-\mathrm{Nimr}$ et al. [34] presented a mathematical model to describe the effects of using silver-water nanofluid on the thermal performance of a shallow solar pond (SSP) and showed that the energy stored in the nanofluid pond is about $216 \%$ more than the energy stored in the brine pond. The upper layer of the pond is made of mineral oil and the lower layer is made of silver (Ag) water-based nanofluid. Their results showed that for solar radiation of $1000 \mathrm{~W} / \mathrm{m}^{2}$, the nanofluid pond required a depth less than $25 \mathrm{~cm}$ in order to absorb the light, while the brine pond depth must be more than $25 \mathrm{~m}$ to absorb the same amount of light. They attributed the increase of stored energy to the increase in thermal conductivity of the base fluid due to the nanoparticles addition that leads to uniform

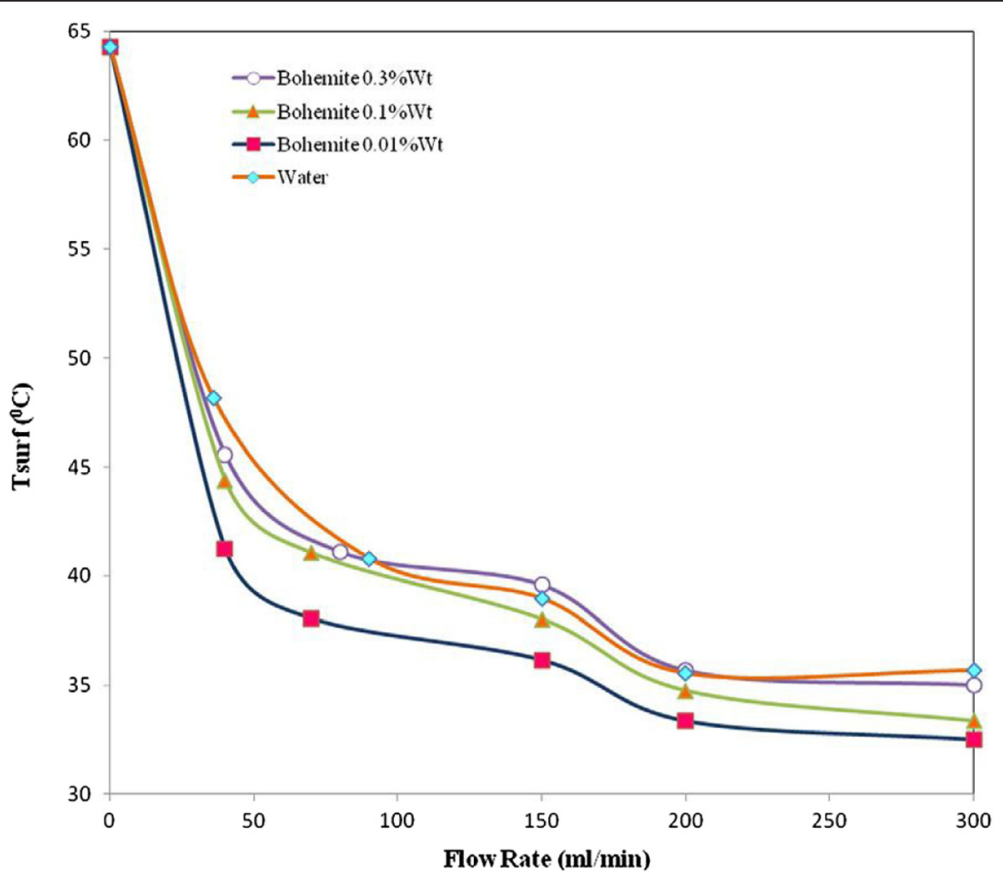

Figure 18 Variation of the average temperatures of the PV surface at various flow rates for water and three different concentrations of nanofluid. 
Table 1 The influence of nanofluid on different solar thermal applications

\begin{tabular}{|c|c|c|c|}
\hline Author(s) & Nanofluid & $\begin{array}{l}\text { Type of } \\
\text { application }\end{array}$ & Observation \\
\hline Luo et al. [8] & $\begin{array}{l}\mathrm{TiO} 2, \mathrm{Al} 2 \mathrm{O} 3, \mathrm{Ag}, \mathrm{Cu}, \mathrm{SiO} 2 \text {, graphite, } \\
\text { and carbon nanotubes in Texatherm } \\
\text { oil }\end{array}$ & $\begin{array}{l}\text { DAC solar } \\
\text { collector }\end{array}$ & $\begin{array}{l}\text { use of nanofluid in the solar collector can improve the outlet temperature } \\
\text { and the efficiency }\end{array}$ \\
\hline $\begin{array}{l}\text { Rahman et } \\
\text { al. [9] }\end{array}$ & $\mathrm{Cu}, \mathrm{Al} 2 \mathrm{O} 3$ and $\mathrm{TiO} 2$ in water & $\begin{array}{l}\text { triangular shape } \\
\text { solar collector }\end{array}$ & $\begin{array}{l}\text { Results showed } 24.28 \% \text { improvement for } \mathrm{Gr}=10^{6} \text { at } 10 \% \text { volume fraction of } \\
\text { copper particles. the convective heat transfer performance is better when } \\
\text { the solid volume fraction is kept at } 0.05 \text { or } 0.08 \text {. }\end{array}$ \\
\hline $\begin{array}{l}\text { Faizal et al. } \\
{[10]}\end{array}$ & $\mathrm{CuO}, \mathrm{SiO} 2, \mathrm{TiO} 2$ and $\mathrm{Al} 2 \mathrm{O} 3$ in water & solar collector & $\begin{array}{l}\text { results confirmed that higher density and lower specific heat of nanofluids } \\
\text { offers higher thermal efficiency than water and therefore can reduce the } \\
\text { solar collector area about } 25.6 \%, 21.6 \%, 22.1 \% \text { and } 21.5 \% \text { for CuO, SiO2, } \\
\mathrm{TiO} 2 \text { and Al2O3 nanofluids. Environmental damage cost is also lower with } \\
\text { the nanofluid based solar collector }\end{array}$ \\
\hline $\begin{array}{l}\text { Parvin et al. } \\
\text { [11] }\end{array}$ & Cu/water & solar collector & $\begin{array}{l}\text { Increasing the particles concentration raises the fluid viscosity and } \\
\text { decreases the Reynolds number and consequently decreases heat transfer. } \\
\text { There is a need to find the optimum volume fraction for each application }\end{array}$ \\
\hline $\begin{array}{l}\text { Ladjevardi } \\
\text { et al. [12] }\end{array}$ & Graphite/water & solar collector & $\begin{array}{l}\text { Their numerical results showed that nanofluid collector thermal efficiency } \\
\text { increases about } 88 \% \text { compared with the pure water collector with the inlet } \\
\text { temperature of } 313 \mathrm{~K} \text {. It also can be increased to } 227 \% \text { with the inlet } \\
\text { temperature of } 333 \mathrm{~K} \text {. }\end{array}$ \\
\hline $\begin{array}{l}\text { Said et al. } \\
{[15]}\end{array}$ & $\begin{array}{l}\text { single wall carbon nanotubes, } \mathrm{Al}_{2} \mathrm{O}_{3}, \\
\mathrm{TiO}_{2} \text { and } \mathrm{SiO}_{2}\end{array}$ & $\begin{array}{l}\text { flat plate solar } \\
\text { collector }\end{array}$ & $\begin{array}{l}\text { It was observed that SWCNTs nanofluids could reduce the entropy } \\
\text { generation by } 4.34 \% \text { and enhance the heat transfer coefficient by } 15.33 \%\end{array}$ \\
\hline $\begin{array}{l}\text { Saidur et al. } \\
{[17]}\end{array}$ & Aluminum/water & $\begin{array}{l}\text { direct absorption } \\
\text { solar collector }\end{array}$ & $\begin{array}{l}\text { Their results revealed that Aluminum/water nanofluid with } 1 \% \text { volume } \\
\text { fraction improves the solar absorption considerably. They found that the } \\
\text { effect of particle size on the optical properties of nanofluid is minimal, but } \\
\text { in order to have Rayleigh scattering the size of nanoparticles should be less } \\
\text { than } 20 \mathrm{~nm} \text {. They also found that the extinction coefficient is linearly } \\
\text { proportionate to volume fraction }\end{array}$ \\
\hline $\begin{array}{l}\text { Sokhansefat } \\
\text { et al. [18] }\end{array}$ & $\mathrm{Al}_{2} \mathrm{O}_{3} /$ synthetic oil & $\begin{array}{l}\text { parabolic trough } \\
\text { collector tube }\end{array}$ & Nanofluid enhanced convective heat transfer coefficient. \\
\hline $\begin{array}{l}\text { Hordy et al. } \\
{[21]}\end{array}$ & $\begin{array}{l}\text { multi-walled carbon nanotubes/water } \\
\text { ethylene glycol, propylene glycol }\end{array}$ & solar collector & $\begin{array}{l}\text { quantitative demonstration of the high temperature and long-term stability } \\
\text { of ethylene glycol and propylene glycol-based MWCNT nanofluids for solar } \\
\text { thermal collectors }\end{array}$ \\
\hline $\begin{array}{l}\text { Said et al. } \\
{[22]}\end{array}$ & Al2O3, water, ethylene glycol & Solar collector & $\begin{array}{l}\text { Their results showed that nanofluids pressure drop at a low concentration } \\
\text { flowing in a solar collector is slightly higher than the base fluid. }\end{array}$ \\
\hline $\begin{array}{l}\text { Liu et al. } \\
\text { [23] }\end{array}$ & $\begin{array}{l}\text { Grapheme/ ionic liquid 1-hexyl-3- } \\
\text { methylimidazolium tetrafluoroborate }\end{array}$ & solar collectors & $\begin{array}{l}\text { They observed } 15.2 \%-22.9 \% \text { enhancement in thermal conductivity using } \\
0.06 \% \text { volume graphene in the temperature range from } 25 \text { to } 200^{\circ} \mathrm{C} \text {. Their } \\
\text { results showed that GE is a better nanoadditive for nanofluids than other } \\
\text { carbon materials and metal nanoparticles }\end{array}$ \\
\hline $\begin{array}{l}\text { Ho et al. } \\
\text { [24] }\end{array}$ & Alumina/ doped molten Hitec & $\begin{array}{l}\text { concentrating } \\
\text { solar power } \\
\text { systems }\end{array}$ & $\begin{array}{l}\text { The addition of less than } 2 \% \mathrm{Al}_{2} \mathrm{O}_{3} \text { nanoparticles significantly increases the } \\
\text { specific heat of Hitec metal at low temperatures }\end{array}$ \\
\hline $\begin{array}{l}\text { Singh et al. } \\
{[25]}\end{array}$ & $\begin{array}{l}\text { Cu/Therminol } 59 \text { (TH59) and } \\
\text { Therminol } 66 \text { (TH66) }\end{array}$ & & $\begin{array}{l}\text { They stated that surfactant selection has an important role in preparing } \\
\text { stable nanofluids. Choosing the right surfactant is mainly dependent on the } \\
\text { properties of the base fluids and particles }\end{array}$ \\
\hline $\begin{array}{l}\text { Yousefi et al. } \\
{[29]}\end{array}$ & MWCNT/water & $\begin{array}{l}\text { flat plate solar } \\
\text { collector }\end{array}$ & $\begin{array}{l}\text { They found that increasing or decreasing the } \mathrm{pH} \text { with respect to the } \mathrm{pH} \text { of } \\
\text { the isoelectric point (IEP) would enhance the positive effect of nanofluids } \\
\text { on the efficiency of the solar collector }\end{array}$ \\
\hline $\begin{array}{l}\text { Sardarabadi } \\
\text { et al. [30] }\end{array}$ & $\mathrm{SiO} /$ water & $\mathrm{PV} / \mathrm{T}$ & $\begin{array}{l}\text { Thermal efficiency of the PV/T collector for the two cases of } 1 \text { and } 3 \text { wt } \% \\
\text { of silica/water nanofluid increased } 7.6 \% \text { and } 12.8 \% \text {, respectively. }\end{array}$ \\
\hline $\begin{array}{l}\text { Kabeel et al. } \\
{[32]}\end{array}$ & Cu/water & $\begin{array}{l}\text { water } \\
\text { desalination unit }\end{array}$ & the water cost can be decreased from 16.43 to $11.68 \$ / \mathrm{m}^{3}$ at $\varphi=5 \%$ \\
\hline $\begin{array}{l}\text { Kabeel et al. } \\
{[33]}\end{array}$ & Al2O3/water & solar still & $\begin{array}{l}\text { using nanofluids improves the solar still water productivity by about 116\% } \\
\text { and } 76 \% \text { with and without operating the vacuum fan }\end{array}$ \\
\hline $\begin{array}{l}\text { Al-Nimr et } \\
\text { al. [34] }\end{array}$ & silver-water & $\begin{array}{l}\text { shallow solar } \\
\text { pond }\end{array}$ & $\begin{array}{l}\text { energy stored in the nanofluid pond is about } 216 \% \text { more than the energy } \\
\text { stored in the brine pond }\end{array}$ \\
\hline $\begin{array}{l}\text { Liu et al. } \\
\text { [35] }\end{array}$ & CuO/water & & $\begin{array}{l}\text { maximum and mean values of the collecting efficiency of the collector } \\
\text { with open thermosyphon using nanofluids increased } 6.6 \% \text { and } 12.4 \% \text {, } \\
\text { respectively. }\end{array}$ \\
\hline
\end{tabular}




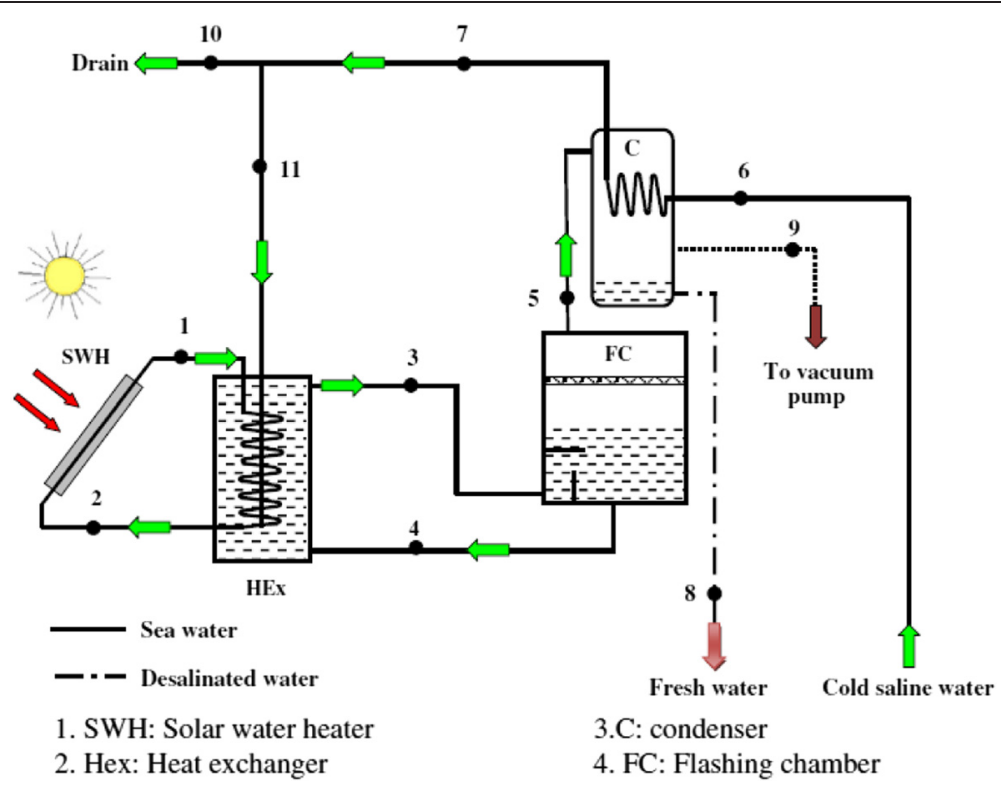

Figure 19 Schematic diagram of single stage flash (SSF) system.

temperature distribution within the layer with reduction in heat losses.

\section{Using nanofluids in the solar collector integrated with open thermosyphon}

Liu et al. [35] experimentally showed that the solar collector integrated with open thermosyphon has a much better collecting performance compared to the collector with concentric tube and its efficiency could be improved by using $\mathrm{CuO}$ /water nanofluid as the working fluid as well. Their results showed that the maximum and mean values of the collecting efficiency of the collector with open thermosyphon using nanofluids increased $6.6 \%$ and $12.4 \%$, respectively.

\section{Conclusions}

Nanofluids have been utilized to improve the efficiency of several solar thermal applications. Theoretical and experimental studies on solar systems proved that the system performance enhances noticeably by using nanofluids. A number of investigations presented the existence of an optimum concentration for nanoparticles in the base fluid.

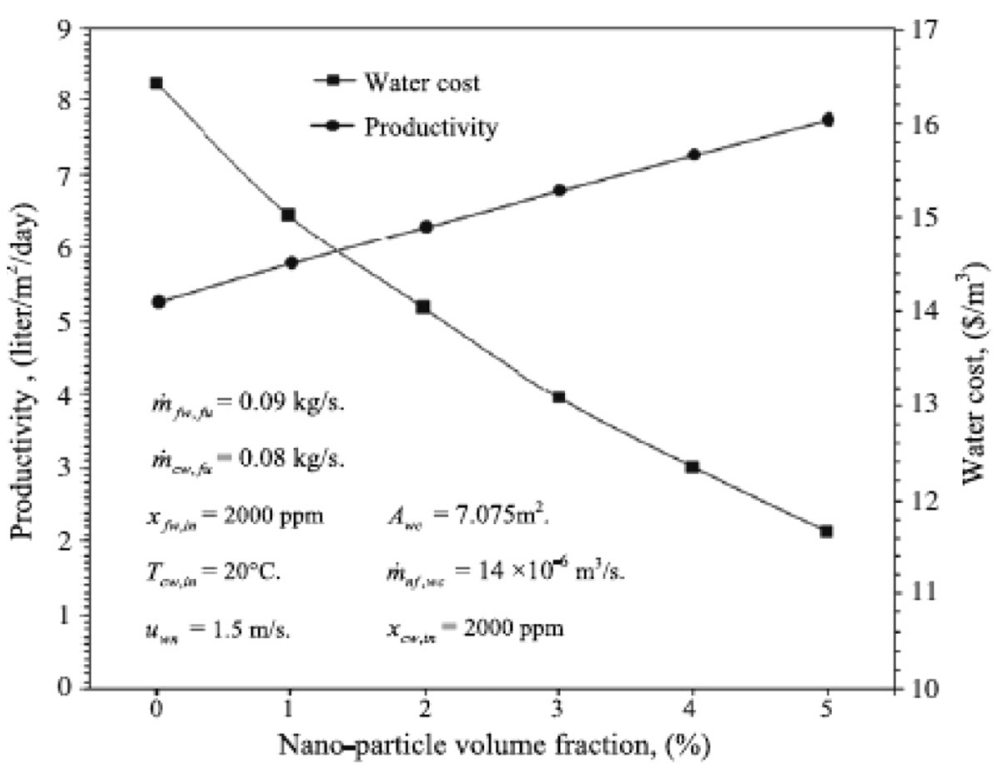

Figure $\mathbf{2 0}$ Variations in system productivity and water cost as a function of nano-particle volume fraction. 
Adding nanoparticles beyond the optimum level no longer enhances the efficiency of the solar system.

Optimal conditions are a function of nanoparticles size and concentration, base fluid, surfactant and $\mathrm{pH}$ as discussed throughout this article. Nanofluid utilization in the solar thermal systems is accompanied by important challenges including high cost of production, instability, agglomeration and erosion. This review article is an attempt to elucidate the advantages and disadvantages of nanofluids application in the solar system.

\section{Competing interests}

The authors declare that they have no competing interests.

\section{Authors' contributions}

MS conducted the extensive literature review and NB wrote the article. Both authors read and approved the final manuscript.

\section{Acknowledgements}

The authors would like to express their appreciation to the Islamic Azad University of Abadan Branch for providing financial support.

\section{Author details}

${ }^{1}$ Mechanical Engineering Department, Abadan Branch, Islamic Azad University, P.O.B. 666, Abadan, Iran. ${ }^{2}$ Mechanical Engineering Department, California State Polytechnic University, Pomona, California, USA.

Received: 4 September 2014 Accepted: 26 January 2015

Published online: 20 May 2015

\section{References}

1. Taylori R, Coulombe S, Otanicar T, Phelan P, Gunawan A, Lv W, Rosengarten G, Prasher R, Tyagi H (2013) Small particles, big impacts: a review of the diverse applications of nanofluids. J Appl Phys 113:011301-011301-19

2. Mahian O, Kianifar A, Kalogirou SA, Pop I, Wongwises S (2013) A review of the applications of nanofluids in solar energy. Int J Heat Mass Transf 57:582-594

3. Said Z, Sajid MH, Saidur R, Kamalisarvestani M, Rahim NA (2013) Radiative properties of nanofluids. Int Commun Heat Mass Transfer 46:74-84

4. Al-Shamani AN, Yazdi MH, Alghoul MA, Abed AM, Ruslan MH, Mat S, Sopian K (2014) Nanofluids for improved efficiency in cooling solar collectors - a review. Renew Sustain Energy Rev 38:348-367

5. Khullar V, Tyagi H, Phelan PE, Otanicar TP, Singh H, Taylor RA (2013) Solar energy harvesting using nanofluids-based concentrating solar collector. J Nanotechnol Eng Med 3:031003-1-9

6. Gan Y, Qiao L (2012) Radiation-enhanced evaporation of ethanol fuel containing suspended metal nanoparticles. Int J Heat Mass Transfer 55:5777-5782

7. Elmir M, Mehdaoui R, Mojtabi A (2012) Numerical simulation of cooling a solar cell by forced convection in the presence of a nanofluid. Energy Procedia 18:594-603

8. Luo Z, Wang C, Wei W, Xiao G, Ni M (2014) Performance improvement of a nanofluid solar collector based on direct absorption collection (DAC) concepts. Int J Heat Mass Transfer 75:262-271

9. Rahman MM, Mojumder S, Saha S, Mekhilef S, Saidur R (2014) Augmentation of natural convection heat transfer in triangular shape solar collector by utilizing water based nanofluids having a corrugated bottom wall. Int Commun Heat Mass Transfer 50:117-127

10. Faizal M, Saidur R, Mekhilef S, Alim MA (2013) Energy, economic and environmental analysis of metal oxides nanofluid for flat-plate solar collector. Energy Convers Manag 76:162-168

11. Parvin S, Nasrin R, Alim MA (2014) Heat transfer and entropy generation through nanofluid filled direct absorption solar collector. Int J Heat Mass Transfer 71:386-395

12. Ladjevardi SM, Asnaghi A, Izadkhast PS, Kashani AH (2013) Applicability of graphite nanofluids in direct solar energy absorption. Sol Energy 94:327-334
13. Filho EPB, Mendoza OSH, Beicker CLL, Menezes A, Wen D (2014) Experimental investigation of a silver nanoparticle-based direct absorption solar thermal system. Energy Convers Manag 84:261-267

14. Karami M, AkhavanBahabadi MA, Delfani S, Ghozatloo A (2014) A new application of carbon nanotubes nanofluid as working fluid of low-temperature direct absorption solar collector. Sol Energy Mater Sol Cells 121:114-118

15. Said Z, Saidur R, Rahim NA, Alim MA (2014) Analyses of exergy efficiency and pumping power for a conventionalflat plate solar collector using SWCNTs based nanofluid. Energy Build 78:1-9

16. Tang B, Wang Y, Qiu M, Zhang S (2014) A full-band sunlight-driven carbon nanotube/PEG/SiO2 composites for solar energy storage. Sol Energy Mater Sol Cells 123:7-12

17. Saidur R, Meng TC, Said Z, Hasanuzzaman M, Kamyar A (2012) Evaluation of the effect of nanofluid-based absorbers on direct solar collector. Int J Heat Mass Transfer 55:5899-5907

18. Sokhansefat $T$, Kasaeian AB, Kowsary F (2014) Heat transfer enhancement in parabolic trough collector tube using Al2O3/synthetic oilnanofluid. Renew Sustain Energy Rev 33:636-644

19. Nasrin R, Parvin S, Alim MA (2013) Effect of Prandtl number on free convection in a solar collector filled with nanofluid. Procedia Engineering 56:54-62

20. Colangelo G, Favale E, de-Risi A, Laforgia D (2012) Results of experimental investigations on the heat conductivity of nanofluids based on diathermic oil for high temperature applications. Appl Energy 97:828-833

21. Hordy N, Rabilloud D, Meunier JL, Coulombe S (2014) High temperature and long-term stability of carbon nanotube nanofluids for direct absorption solar thermal collectors. Sol Energy 105:82-90

22. Said Z, Sajid MH, Alim MA, Saidur R, Rahim NA (2013) Experimental investigation of the thermophysical properties of AL2O3-nanofluid and its effect on a flat plate solar collector. Int Commun Heat Mass Transfer 48:99-107

23. Liu J, Wang F, Zhang L, Fang X, Zhang Z (2014) Thermodynamic properties and thermal stability of ionic liquid-based nanofluids containing graphene as advanced heat transfer fluids for medium-to-high-temperature applications. Renew Energy 63:519-523

24. Ho MX, Pan C (2014) Optimal concentration of alumina nanoparticles in molten Hitec salt to maximize its specific heat capacity. Int J Heat Mass Transfer 70:174-184

25. Singh D, Timofeeva EV, Moravek MR, Cingarapu S, Yu W, Fischer T, Mathur S (2014) Use of metallic nanoparticles to improve the thermophysical properties of organic heat transfer fluids used in concentrated solar power. Sol Energy 105:468-478

26. Yousefi T, Veysi F, Shojaeizadeh E, Zinadini S (2012) An experimental investigation on the effect of $\mathrm{Al} 2 \mathrm{O} 3-\mathrm{H} 2 \mathrm{O}$ nanofluid on the efficiency of flat-plate solar collectors. Renew Energy 39:293-298

27. Yousefi, F. Veysy, E. Shojaeizadeh, S. Zinadini (2012). An experimental investigation on the effect of MWCNT-H2O nanofluid on the efficiency of flat-plate solar collectors. Experimental Thermal and Fluid Science 207-212

28. Lenert A, Wang EN (2012) Optimization of nanofluid volumetric receivers for solar thermal energy conversion. Sol Energy 86:253-265

29. Yousefi T, Shojaeizadeh E, Veysi F, Zinadini S (2012) An experimental investigation on the effect of $\mathrm{pH}$ variation of MWCNT-H2O nanofluid on the efficiency of a flat-plate solar collector. Sol Energy 86:771-779

30. Sardarabadi M, Passandideh-Fard M, Zeinali Heris S (2014) Experimental investigation of the effects of silica/water nanofluid on PV/T (photovoltaic thermal units). Energy 66:264-272

31. Karami N, Rahimi M (2014) Heat transfer enhancement in a hybrid microchannel-photovoltaic cell using Boehmite nanofluid. Int Commun Heat Mass Transfer 55:45-52

32. Kabeel AE, El-Said EMS (2014) Applicability of flashing desalination technique for small scale needs using a novel integrated system coupled with nanofluid-based solar collector. Desalination 333:10-22

33. Kabeel AE, Omara ZM, Essa FA (2014) Enhancement of modified solar still integrated with external condenser using nanofluids: An experimental approach. Energy Convers Manag 78:493-498

34. Al-Nimr MA, Al-Dafaie AMA (2014) Using nanofluids in enhancing the performance of a novel two-layer solar pond. Energy 68:318-326

35. Liu ZH, Hu RL, Lu L, Zhao F, Xiao HS (2013) Thermal performance of an open thermosyphon using nanofluid for evacuated tubular high temperature air solar collector. Energy Convers Manag 73:135-143 